\title{
Removal of ochratoxin A by wine Saccharomyces cerevisiae strains
}

\author{
M. Piotrowska $\cdot$ A. Nowak $\cdot$ A. Czyzowska
}

Received: 5 September 2012/Revised: 21 December 2012/Accepted: 21 December 2012/Published online: 10 January 2013

(C) The Author(s) 2013. This article is published with open access at Springerlink.com

\begin{abstract}
The aim of this work was to examine two wine strains of Saccharomyces cerevisiae (Syrena LOCK 0201 and Malaga LOCK 0173 strains) and thermally inactivated biomass of bakery yeast (BS strain) for their ability to remove ochratoxin A (OTA) from model YPG, white grape GM, and blackcurrant BM media. The media was initially contaminated by $1 \mu \mathrm{g} / \mathrm{mL}$ OTA. The influence of OTA on yeast growth parameters, kinetic of fermentation, and amount of ethanol, glycerol, and acids were determined. It was found that both yeast strains were able to decrease the toxin amount in YPG, GM, and BM media. Strain Malaga LOCK 0173 was able to remove 82.8 and $10.7 \%$ ochratoxin A from grape and blackcurrant medium, respectively. In case of Syrena LOCK 0201 strain, the OTA reduction was higher: $85.1 \%$ for grape and $65.2 \%$ for blackcurrant media. From 54.1 to $64.4 \%$ of initial ochratoxin A concentration was removed after the contaminated wine treatment by thermally inactivated baker's yeast strain (BS) cells. The elongation of lag phase in contaminated YPG medium compared on toxin-free medium was noted. In white grape and blackcurrant medium, the differences between the final cell number, fermentation rate, moreover the ethanol, glycerol, and acids production in the medium with OTA and the control were not statistically significant. The results showed that the application of selected strains of yeasts in winemaking involving raw material contaminated with OTA might reduce the toxin contamination as well as the health risk related to human exposure to this toxin. Moreover, the application of heat-inactivated yeast's
\end{abstract}

M. Piotrowska $(\varangle) \cdot$ A. Nowak · A. Czyzowska Faculty of Biotechnology and Food Science, Institute of Fermentation Technology and Microbiology, Technical University of Lodz, Wolczanska 171/173, 90-924 Lodz, Poland e-mail: malgorzata.piotrowska@p.lodz.pl biomass for toxin adsorption gives new possibilities in oenology.

Keywords Ochratoxin A - Saccharomyces cerevisiae . Detoxification · Fermentation · Adsorption

\section{Introduction}

Ochratoxin A is very widely detected in raw material and food products such as cereals, bread, coffee, dried wine fruits, as well as in beverages, for example beer, grape juice, and wine [1-7]. This toxin is produced by numerous fungal species belonging to the genera Aspergillus and Penicillium. The primary OTA-producing species associated with grapes belong to Aspergillus genera, section Nigri (black aspergilla), and including Aspergillus niger var. niger, A. niger var. awamori, A. carbonarius, A. foetidus, A. biseriate, and A. uniserate $[8,9]$. Factors affecting wine contamination by ochratoxin A and their occurrence in red, rose, white, and special wines are reviewed in several articles $[5-7,10]$.

The presence of OTA in wine is mainly a result of fungal contamination on grapes both at pre and postharvest. This toxin is more prevalent in wines originating from the Mediterranean basin, less from Australia and South America $[2,4,11,12]$. There is no information about the distribution of OTA in fruit alcohol beverages, which are popular in some countries, for example in Poland. Ochratoxin A contamination of commodities is a serious health problem due to their carcinogenic, nephrotoxic, genotoxic, and teratogenic properties [13]. In order to protect consumers, the EU Committee has established the maximum OTA levels for wines and musts at $2 \mu \mathrm{g} / \mathrm{L}$ [14].

In order to minimize the risk of OTA contamination, the preventive actions including the selection and proper 
storage of raw material are used. Such actions are not always completely effective. Several possibilities are available as for the detoxification of mycotoxins, including physical and chemical methods [15-18].

Few of these have practical application, for example various inorganic adsorbent such as aluminosilicates, zeolites, bentonites, clays, and activated carbon. The using of these agents has a lot of disadvantages; in many cases, they decrease the nutritive value and organoleptic properties or significantly increase the cost of food and feed production $[17,18]$. Recently, an increase in the research connected with mycotoxin detoxification by microorganisms has been observed. Several studies showed that some bacteria, moulds, and yeasts, for example Lactobacillus acidophilus, Bifidobacterium animalis, Oenococcus oeni, Aspergillus niger, A. carbonarius, A. fumigatus, Saccharomyces cerevisiae, and Kloeckera apiculata are able to detoxify mycotoxins [19-25].

Recent investigations demonstrate that Saccharomyces cerevisiae strains are able to remove OTA from plant raw material during fermentation of wine, beer, or sourdough [23, 26-29]. Some authors reported decreasing ochratoxin levels during winemaking [26, 27, 30-32]. In previous work, we suggested that physical binding to the yeasts biomass might be responsible for ochratoxin A decrease [33]. The compounds of the yeast's cell wall that are involved in the binding process are probably $\beta$-D-glucan and its esterified form. The oenological function of parietal yeast mannoproteins is reviewed by Caridi [34].

In the presented study, two wine strains of Saccharomyces yeasts were examined for their ability to remove ochratoxin A from grape and blackcurrant juice. The influence of OTA on fermentation and yeast metabolism were investigated too.

\section{Materials and methods}

\section{Yeast strains}

The following strains of Saccharomyces cerevisiae were used in this study: wine strains Malaga LOCK 0173, Syrena ŁOCK 0201, and bakery BS strain. These strains were selected for their ability of OTA removal in previous works $[33,35]$. All strains were received from the Collection of Industrial Microorganisms of the Institute of Fermentation Technology and Microbiology, Technical University of Lodz.

The yeast strains were stored on YPG slants (yeast extract $1 \%$, peptone $2 \%$, glucose $2 \%$, agar $1.5 \%$ ) at $4{ }^{\circ} \mathrm{C}$ and transferred to new slants once a month. Before carrying out the experiments, the strains were activated in $50 \mathrm{~mL}$ of liquid YPG medium in $100-\mathrm{mL}$ flasks at $30^{\circ} \mathrm{C}$ for $24 \mathrm{~h}$ on an orbital shaker (160 rpm). Yeasts biomass was collected by centrifugation $(1,500 \mathrm{~g}, 10 \mathrm{~min})$ and suspended in $0.85 \% \mathrm{NaCl}$ (normal saline) at cell concentration of about $10^{8} \mathrm{cfu} / \mathrm{mL}$.

Additionally, biomass of baker's yeasts BS strains was suspended in normal saline $(100 \mathrm{mg} / \mathrm{mL})$, thermally inactivated in autoclave $\left(121^{\circ} \mathrm{C}, 20 \mathrm{~min}\right)$ and used in the further investigation.

\section{Chemicals}

All chemicals and solvents used were purchased from SIGMA-Aldrich, St. Louis, MO, USA, and were of analytical grade. Water from a Millipore Milli-Q system was used for all solutions, dilution, and the mobile phase for HPLC. Sulphuric acid (95-98 \%) was obtained from J.T. Baker B.V. (Deventer, Holland). Organic acids used as standards were purchased from Supelco (Bellefonte, PA).

Ochratoxin A (SIGMA-Aldrich, St. Louis, MO, USA) was stored as stock solution in absolute ethanol (HPLC grade) at $-20{ }^{\circ} \mathrm{C}$. The concentration of OTA was $200 \mu \mathrm{g} / \mathrm{mL}$.

\section{Ochratoxin A removal assay}

The OTA removal capacity of yeast was tested in YPG liquid medium as well as in media prepared from commercial concentrates of white grape juice and blackcurrant juice (Sonda Inc., Poland). The media for wine fermentation were prepared according to [36] by diluting white grape and blackcurrant concentrates to $12 \mathrm{Brix}^{\circ}$ (1 $\mathrm{Brix}^{\circ}$ means 1 weight percentage of reducing sugars). YPG medium was sterilized at $117^{\circ} \mathrm{C}, 15 \mathrm{~min}$. All media were contaminated with ochratoxin A stock solution to obtain the initial concentration of $1 \mu \mathrm{g} / \mathrm{mL}$ OTA. The media were then inoculated with the yeast biomass suspended in $0.85 \% \mathrm{NaCl}$. The initial concentration of yeast was about $10^{6}$ cells $/ \mathrm{mL}$. The experiments in YPG medium were conducted in static conditions at $30{ }^{\circ} \mathrm{C}$ for $24 \mathrm{~h}$. The fermentation of grape and blackcurrant medium in volume $200 \mathrm{~mL}$ was conducted in 250-mL flasks with a fermentation lock (gas trap) at $30^{\circ} \mathrm{C}$. During 10 days of fermentation, the weight loss and $\mathrm{CO}_{2}$ production were monitored. The media not inoculated with the yeasts and inoculated but not contaminated with ochratoxin A served as control samples.

The possibility of binding ochratoxin A by thermally inactivated cells was tested in $50 \mathrm{~mL}$ YPG medium, grape, and blackcurrant wine obtained by fermentation by Syrena LOCK 0201 strain. The media were artificially contaminated by OTA to concentration $1 \mu \mathrm{g} / \mathrm{mL}$. The baker's strain BS biomass was added to media to achieve concentrations of $5 \mathrm{mg} / \mathrm{mL}$. The samples were kept at $30{ }^{\circ} \mathrm{C}$ for $24 \mathrm{~h}$. All experiments were conducted in three independent samples. 
Determination of cells number

A standard plate method on RBC medium (Rose Bengal Chloramphenicol, Merck, Darmstadt, Germany) was used for determination of the number of cells. The initial and final number of cells on musts and wines were estimated. In case of YPG medium, the number of cells before and during cultivation (at 2-h intervals) was determined. The results were expressed as cfu/mL.

The cell numbers on YPG medium were fitted to the Gompertz equation using an Excel add-in, DMFit 2.1 (Institute of Ford Research, Norwich, UK): $L(t)=A+$ $C \exp \{-\exp [-B(t-M)]\}$.

The following growth parameters were estimated according to [37]:

$\mu_{\max }=B C / e$

where $\mu_{\max }$ is the maximum specific growth rate $\left[\mathrm{h}^{-1}\right]$, $B$ and $C$ are the constant from Gompertz equation

$t$ Lag $=M-(1 / B)$

where $t \mathrm{Lag}$ is the lag time (h), $M$ and $B$ are the constant from Gompertz equation.

Ochratoxin A analysis

The estimation of OTA in YPG medium and in raw materials after removing the biomass by centrifugation $(1,500 \mathrm{~g}, 10 \mathrm{~min})$ was performed before (at time $=0)$ and after the fermentation or binding process with dead cells. Samples were purified by the use of immunoaffinity column OchraStar ${ }^{\circledR}$ (Romer Labs ${ }^{\circledR}$ Diagnostic GmbH, Tulln, Austria). Ochratoxin A was analysed by Finnigan ${ }^{\mathrm{TM}}$ Surveyor Plus ${ }^{\mathrm{TM}}$ HPLC System (Thermo Separation Products, Riviera Beach Fl., USA) equipped with an autosampler system, using a C18 Ace column $(25 \mathrm{~cm} \times 4.6 \mathrm{~mm}, 5 \mu \mathrm{m}$ particles) at room temperature. Samples $(100 \mu \mathrm{L})$ were injected (Rheodyne, Cotati, USA), eluted by water/acethonitrile/glacial acetic acid (99:99:2 v/v) at a flow rate of $1.0 \mathrm{~mL} / \mathrm{min}$, and detected with fluorescence detector (Finnigan Surveyor FL Plus Detector) at $\lambda_{\text {excitation }}=$ $330 \mathrm{~nm}$ and $\lambda_{\text {emission }}=460 \mathrm{~nm}$.

The decrease of ochratoxin $\mathrm{A}$ in the medium in relation to the initial concentration was expressed in percentage.

Determination of fermentation products

The presence of fermentation products in wines (ethanol, glycerol, and acids) was determined according to Gutarowska and Czyzowska [38] by HPLC method using Finnigan Surveyor chromatograph equipped with a refractive index detector (Finnigan Surveyor-RI Plus detector), a diode array detector (Finnigan Surveyor-PDA
Plus detector), and a Aminex HPX-87H column $(300 \times 7.8 \mathrm{~mm})$. The chromatographic analysis was performed at $60{ }^{\circ} \mathrm{C}$ using sulphuric acid $(5 \mathrm{mmol} / \mathrm{L})$ as the eluent at a flow rate of $0.6 \mathrm{~mL} / \mathrm{min}$ with a sample volume of $10 \mu \mathrm{L}$. Quantitation was based on the peak area measurement. This experiment was carried out only for one strain-Syrena LOCK 0201.

\section{Statistical analysis}

All experiments were conducted in triplicate. For the date statistical analysis, the Microcal ORIGIN ver. 6.0 software (Northampton, USA) was used. The resulting data were subjected to statistical analysis, including determination of the arithmetic mean, standard deviation, and variance analysis (one-way ANOVA test). Probability $(P)$ values of $<0.05$ were considered significant. For modelling of yeasts growth on YPG medium and estimating of growth parameters, the Gompertz model was used.

\section{Results and discussion}

There were no significant differences observed $(P<0.05)$ between ochratoxin A concentration before and after 10 days incubation of contamination media without yeasts (control samples). Both wine strains were able to decrease the initial OTA concentration in the artificial YPG medium (Table 1). A reduction of 21.0 and $35.4 \%$ was measured for the strains Syrena LOCK 0201 and Malaga LOCK 0173, respectively. Similar results were reported by Bejaoui et al. A significant decrease of OTA levels in YPG medium (11-45\%) after 6 days of fermentation with oenological Saccharomyces strains was observed [27].

In the white grape must fermented with the two yeast strains, the OTA levels clearly decreased after fermentation, and reduction levels exceeding of $80 \%$ were noted (Table 1). There are no significant differences $(P<0.05)$ between strains. The experiment with blackcurrant must

Table 1 The reduction of ochratoxin A in model and natural media

\begin{tabular}{llll}
\hline Strains & \multicolumn{3}{c}{ \% Reduction of ochratoxin A (mean \pm SD) } \\
\cline { 2 - 4 } & YPG + OTA & GM + OTA & BM + OTA \\
\hline Syrena LOCK 0201 & $21.0 \pm 2.10^{\mathrm{a}}$ & $85.1 \pm 6.02^{\mathrm{b}}$ & $65.2 \pm 2.35^{\mathrm{b}}$ \\
Malaga LOCK 0173 & $35.4 \pm 1.82^{\mathrm{a}}$ & $82.8 \pm 2.90^{\mathrm{b}}$ & $10.7 \pm 2.32^{\mathrm{b}}$ \\
$\begin{array}{l}\text { BS (thermolized } \\
\text { biomass) }\end{array}$ & $54.1 \pm 1.75^{\mathrm{a}}$ & $64.4 \pm 1.54^{\mathrm{a}}$ & $62.4 \pm 1.12^{\mathrm{a}}$ \\
\hline
\end{tabular}

$Y P G$ yeast extract, peptone, glucose medium, $G M$ grape medium, $B M$ blackcurrant medium, OTA ochratoxin A

Values represented the means of triplicate determinations \pm SD, ${ }^{\mathrm{a}}$ Results after $24 \mathrm{~h},{ }^{\mathrm{b}}$ Results after 10 days of fermentation 
Table 2 The effect of ochratoxin A on yeast's growth

\begin{tabular}{|c|c|c|c|c|c|c|c|}
\hline \multirow[t]{2}{*}{ Strains } & \multirow[t]{2}{*}{ Parameter } & \multicolumn{6}{|l|}{ Medium } \\
\hline & & YPG + OTA & YPG & $\mathrm{GM}+\mathrm{OTA}$ & GM & $\mathrm{BM}+\mathrm{OTA}$ & $\mathrm{BM}$ \\
\hline \multirow{3}{*}{$\begin{array}{l}\text { Malaga LOCK } \\
0173\end{array}$} & $t \operatorname{Lag}(\mathrm{h})$ & $14.31 \pm 0.46^{\mathrm{a}}$ & $10.63 \pm 0.61^{\mathrm{b}}$ & nd & nd & nd & nd \\
\hline & $\mu_{\max }\left(\mathrm{h}^{-1}\right)$ & $0.33 \pm 0.04^{\mathrm{a}}$ & $0.19 \pm 0.01^{\mathrm{b}}$ & nd & nd & nd & nd \\
\hline & $\begin{array}{l}\text { Biomass concentration } \\
\left(\times 10^{7} \mathrm{cfu} / \mathrm{mL}\right)\end{array}$ & $5.03 \pm 0.10^{\mathrm{a}}$ & $5.40 \pm 0.10^{\mathrm{a}}$ & $1.16 \pm 0.27^{\mathrm{b}}$ & $1.38 \pm 0.27^{\mathrm{b}}$ & $0.57 \pm 0.08^{c}$ & $0.68 \pm 0.13^{\mathrm{c}}$ \\
\hline \multirow{3}{*}{$\begin{array}{l}\text { Syrena LOCK } \\
0201\end{array}$} & $t \operatorname{Lag}(\mathrm{h})$ & $16.35 \pm 0.36^{\mathrm{a}}$ & $11.91 \pm 0.26^{\mathrm{b}}$ & nd & nd & nd & nd \\
\hline & $\mu_{\max }\left(\mathrm{h}^{-1}\right)$ & $0.57 \pm 0.01^{\mathrm{a}}$ & $0.367 \pm 0.01^{\mathrm{b}}$ & nd & nd & nd & nd \\
\hline & $\begin{array}{l}\text { Biomass concentration }\left(\times 10^{7}\right. \\
\mathrm{cfu} / \mathrm{mL})\end{array}$ & $9.82 \pm 0.46^{\mathrm{a}}$ & $15.37 \pm 0.30^{\mathrm{d}}$ & $2.57 \pm 0.17^{\mathrm{c}}$ & $2.74 \pm 0.20^{\mathrm{c}}$ & $1.69 \pm 0.52^{\mathrm{b}}$ & $2.03 \pm 0.26^{\mathrm{b}}$ \\
\hline
\end{tabular}

$Y P G$ yeast extract, peptone, glucose medium, $G M$ grape medium, $B M$ blackcurrant medium, OTA ochratoxin A, $n d$ not determined Values represented the means of triplicate determinations \pm SD. Different letters in the same line indicate significant differences $(P<0.05)$

shows differences between strains. Syrena LOCK 0201 strain is able to remove about 6 times more OTA than Malaga LOCK 0173 strain in the same condition. It demonstrated that removing of ochratoxin A from media depends on type of musts and on strains. These results showed the high capacity of both yeast strains to decreasing the OTA concentration during white wine processing and are in accordance with data published by Cecchini et al. [26]. They found that yeast strains after 36 days of white grape must fermentation remove about $50 \%$ of the initial OTA amount $(2 \mu \mathrm{g} / \mathrm{L})$ and argued that the reduction of the mycotoxin was due to adsorption to the cell walls of the yeasts. Similar results were showed by Caridi et al. [30]. After 90 days of naturally OTA contaminated grape must fermentation, the amount of toxin decrease from 40 to $80 \%$ depends on the strain. In both studies, the concentration of toxins was lower and the time of contact between the yeast and the OTA was longer than in our research.

The reduction of OTA level after treatment of contaminated GM and BM media after fermentation by thermally inactivated biomass of yeasts was observed too. From 54.1 to $64.4 \%$ of initial ochratoxin A concentration was removed (Table 1). The higher adsorption from fermented GM and BM media than from YPG medium was observed. These results are corresponding with previous reports that described adsorption of some mycotoxins by heat-inactivated yeasts [27]. The authors found that the OTA removal from synthetic grape juice by heat-treated yeasts reached $75 \%$ after $2 \mathrm{~h}$ of incubation, but the biomass concentration was higher than in our research. Better decontamination ability of killed cells against the viable cells indicates the physical nature of binding. The adsorption to cell wall is suggested as a mechanism of this phenomenon [27, 33]. Cell wall components play a significant role in mycotoxin binding, especially outer layer consisting of mannoproteins. Heating may cause changes in the surface properties of

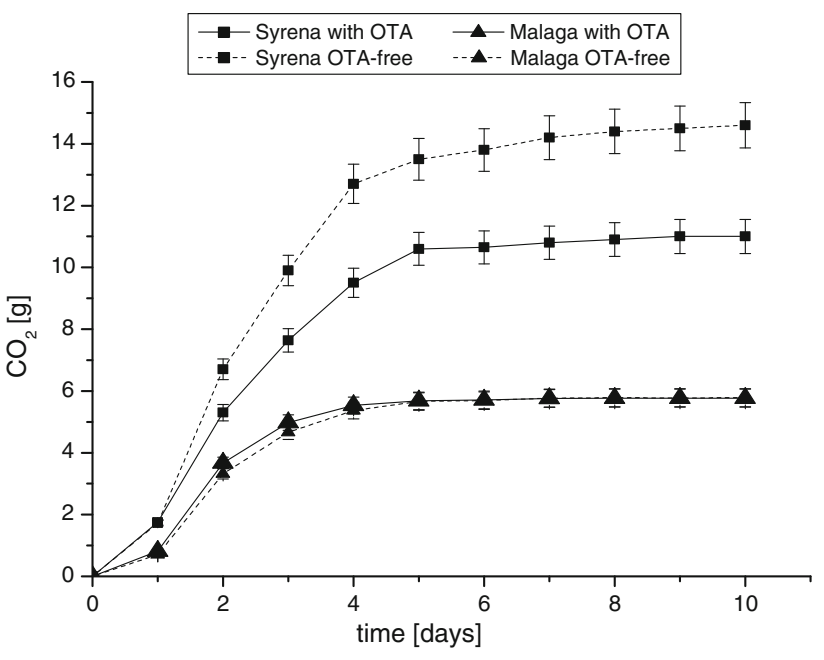

Fig. 1 Fermentation profiles in white grape medium

cells, for example denaturation of proteins or formation of Maillard reaction products. These products could possess more adsorption sites than viable cells. Moreover, the changes in cell wall thickness, increase of pore size, and permeability under heat treatment were observed [39]. The use of inactive dry yeasts in the oenological industry to improve technological processes, sensory characters, or to avoid negative impact of OTA on human health is recently reviewed by Pozo-Bayon et al. [40]. The application of killed cells as adsorbent for the purpose of elimination of ochratoxin A, for example from wine, is highly advantageous since such biomass does not change organoleptic features of end products. But the polyphenols may adsorb to the same binding sites on the surface of cells. It makes that this method is more useful rather for white wines than for red. It has been shown that various types of commercial fining agents using in oenology, such as activated carbon, silica gel, bentonite, and gelatin have the capacity to remove 
OTA too [41]. According to Castellari et al. activated carbon and silica gel in the dosage of about 10 and $100 \mathrm{mg} / \mathrm{L}$, respectively, are able to adsorb after $12 \mathrm{~h}$ about $50-60 \%$ of OTA from red wines. The dosage of fining agents was about 50 times less than in our research, and the concentration of OTA was also low at $3.78 \mathrm{ng} / \mathrm{mL}$. Activated carbon also removes anthocyanins and other polyphenols from wine, but only in high amount of adsorbent, exceeding $50 \mathrm{~g} / \mathrm{L}$ [41].

In Table 2, the effect of OTA on yeast's growth is summarized. The inhibitory effect of OTA contamination on biomass yield was observed only for Syrena LOCK 0201 strain in YPG medium. The final cell number of this strain after $24 \mathrm{~h}$ in YPG medium with OTA was $9.8 \times 10^{7} \mathrm{cfu} / \mathrm{mL}$, whereas in control sample, $1.5 \times$ $10^{8} \mathrm{cfu} / \mathrm{mL}$. For Malaga LOCK 0173 strains on YPG medium, no differences were observed. The elongation of lag phase on contaminated YPG medium compared on

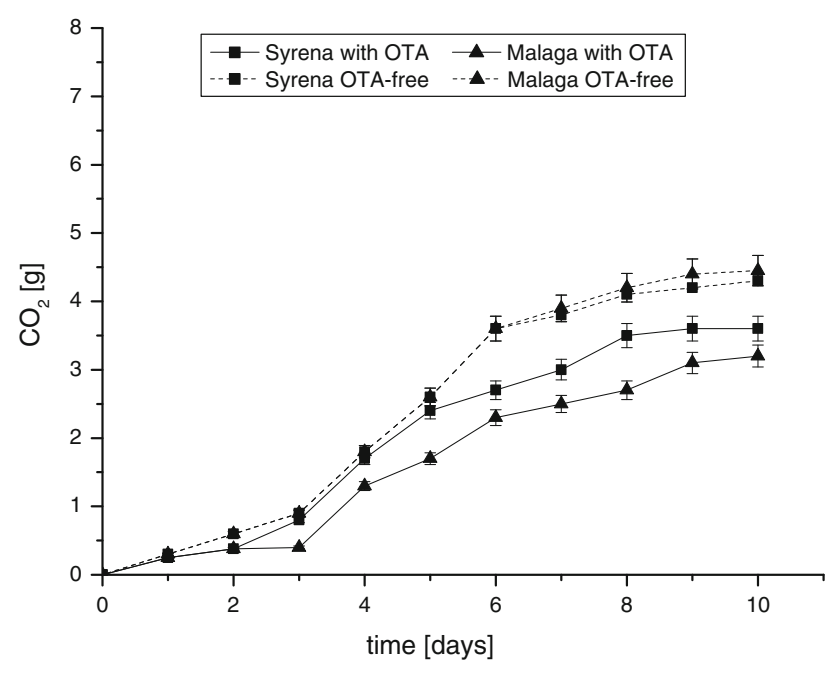

Fig. 2 Fermentation profiles in blackcurrant medium toxin-free medium was noted (Table 2). In white grape and blackcurrant medium, the differences between the final cell number in the medium with OTA and the control were not statistically significant $(P<0.05)$. These results demonstrate the absence of a negative effect of a toxin on biomass yield. The effect of ochratoxin $\mathrm{A}$ on the fermentation rate measured as the weight loss $\left(\mathrm{CO}_{2}\right.$ evolution) during 10 days of fermentation was presented on Figs. 1 and 2. It was observed that for Syrena LOCK 0201 strain, the fermentation of white grape medium was more dynamic in the toxin-free medium than in the contaminated. In case of Malaga LOCK 0173 strain, the inhibitory effect of OTA on the fermentation kinetic was not found. The fermentation of blackcurrant medium was less effective. About $4.5 \mathrm{~g}$ of carbon dioxide was released, while in grape medium, it was 15 and $6 \mathrm{~g}$ for Syrena LOCK 0201 and Malaga LOCK 0173 strains, respectively. The inhibitory effect of ochratoxin A on the course of fermentation was observed (Fig. 2) in case of both strains.

Syrena LOCK 0201 strain was able to produce (in average) 73 and $49 \mathrm{~g} / \mathrm{L}$ of ethanol on grape and blackcurrant medium, respectively, after 10 days. On BM, the production of glycerol was twice higher than on GM. The blackcurrant wines contented more acids: acetic, succinic, and citric than white grape medium (Table 3). There are no significant differences in amount of ethanol, glycerol, and acids $(P<0.05)$ between the media contaminated with ochratoxin A and toxin-free. The results of this part of the experiment indicated that contamination of raw material with ochratoxin A did not significantly influence the rate of fermentation and technological properties of winemaking. This statement is contrary to Bizaj et al. [42] which observed that the presence of OTA in synthetic media influenced yeasts metabolism, especially higher volatile acidity production. On the other side, according to Meca et al. [32], ochratoxin presence in must did not affect the alcoholic fermentation of Italian red wine Moscato.

Table 3 The influence of ochratoxin A on ethanol, glycerol, and acids content in wine fermented by Syrena LOCK 0201 strain

\begin{tabular}{|c|c|c|c|c|}
\hline \multirow[t]{2}{*}{ Product (g/L) } & \multicolumn{4}{|l|}{ Medium } \\
\hline & GM & $\mathrm{GM}+$ OTA & $\mathrm{BM}$ & $\mathrm{BM}+$ OTA \\
\hline Ethanol & $73.94 \pm 1.69^{\mathrm{a}}$ & $72.23 \pm 1.19^{\mathrm{a}}$ & $50.09 \pm 1.06^{\mathrm{b}}$ & $48.13 \pm 1.17^{\downarrow}$ \\
\hline Glycerol & $4.66 \pm 0.28^{\mathrm{a}}$ & $4.54 \pm 0.25^{\mathrm{a}}$ & $8.35 \pm 0.37^{\mathrm{b}}$ & $8.16 \pm 0.23^{b}$ \\
\hline Acetic acid & $0.49 \pm 0.09^{\mathrm{a}}$ & $0.42 \pm 0.08^{\mathrm{a}}$ & $1.91 \pm 0.11^{\mathrm{b}}$ & $1.74 \pm 0.12^{\mathrm{b}}$ \\
\hline Lactic acid & nd & $0.13 \pm 0.05$ & nd & nd \\
\hline Succinic acid & $0.31 \pm 0.09^{\mathrm{a}}$ & $0.42 \pm 0.07^{\mathrm{a}}$ & nd & $0.54 \pm 0.06$ \\
\hline Citric acid & $0.46 \pm 0.05^{\mathrm{a}}$ & $1.94 \pm 0.06^{\mathrm{c}}$ & $10.11 \pm 1.3^{\mathrm{b}}$ & $11.48 \pm 1.65^{\mathrm{b}}$ \\
\hline
\end{tabular}

$G M$ grape medium, $B M$ blackcurrant medium, $n d$ not detected [under limit of detection $(0.01 \mathrm{~g} / \mathrm{L})$ ]

Values represented the means of triplicate determinations \pm SD. Different letters in the same line indicate significant differences $(P<0.05)$ 


\section{Conclusions}

Ochratoxin A contamination of grapes and grape products is a serious problem in oenological practise. The presented results showed that the application of selected strains of yeasts in biotechnological processes such as winemaking involving raw material contaminated with OTA might reduce the toxin contamination as well as the health risk related to human exposure to this toxin. Moreover, the application of heat-inactivated yeast's biomass for toxin adsorption gives new possibilities in oenology. Further studies are needed to clarify the mechanism of binding, as well as perform the economic calculation of cost-effectiveness of this method of wine decontamination.

Open Access This article is distributed under the terms of the Creative Commons Attribution License which permits any use, distribution, and reproduction in any medium, provided the original author(s) and the source are credited.

\section{References}

1. Petzinger E, Ziegler K (2000) Ochratoxin A from a toxicological perspective. J Vet Pharmacol Ther 23:91-98

2. Pietri A, Bertuzzi T, Pallaroni L, Piva G (2001) Occurrence of ochratoxin A in Italian wines. Food Addit Contam 18(7):647-654

3. Delage N, d'Harlingue A, Colonna Ceccaldi B, Bompeix G (2003) Occurrence of mycotoxins in fruit juices and wine. Food Control 14:225-227

4. Battilani P, Magan N, Logrieco A (2006) European research on ochratoxin A in grapes and wine. Int J Food Microbiol 111:S2-S4

5. Varga J, Kozakiewicz Z (2006) Ochratoxin A in grapes and grape-derived products. Trends Food Sci 17:72-81

6. Valero A, Marin S, Ramos AJ, Sanchis V (2008) Survey: ochratoxin A in European special wines. Food Chem 108:593-599

7. Mateo R, Medina A, Mateo EM, Mateo F, Jimenez M (2007) An overview of ochratoxin A in beer and wine. Int J Food Microbiol 119:79-83

8. Cabanes FJ, Accensi F, Bragulat MR, Abarca ML, Castella G, Minguez S, Pons A (2002) What is the source of ochratoxin A in wine. Int J Food Microbiol 79:213-215

9. Sage L, Krivobok S, Delbos E, Seigle-Murandi F, Greppy EE (2002) Fungal flora and ochratoxin A production in grapes and musts from France. J Agric Food Chem 50:1306-1311

10. Blesa J, Soriano JM, Moloto JC, Manes J (2006) Factors affecting the presence of ochratoxin A in wines. Crit Rev Food Sci Nutr 46:473-478

11. Leong SL, Hocking AD, Pitt JI, Kazi BA, Emmett RW, Scott ES (2006) Australian research on ochratoxigenic fungi and ochratoxin A. Int J Food Microbiol 111:S10-S17

12. Da Rocha Rosa CA, Palacios V, Combina M, Fraga MF, de Iliveira Rekson A, Magnoli CE, Dalcero AM (2002) Potential ochratoxin A producers from wine grapes in Argentina and Brasil. Food Addit Contam 19:408-414

13. Reddy L, Bhoola K (2010) Ochratoxins-food contaminants: impact on human health. Toxins 2:771-779

14. Anonymous (2001) Commission Regulation (EC) 466/2001 setting maximum levels for certain contaminants in foodstuffs. Off J Eur Union L77:1-13
15. Kabak B, Dobson A (2006) Strategies to prevent mycotoxin contamination of food and animal feed: a review. Crit Rev Food Sci Nutr 46(8):593-619

16. Doyle MP, Applebaum RS, Brackett RE, Marth EH (1982) Physical, chemical and biological degradation of mycotoxins in foods and agricultural commodities. J Food Prot 45:964-971

17. Huwig A, Freimund S, Kappeli O, Dutler H (2001) Mycotoxin detoxication of animal feed by different adsorbents. Toxicol Lett 122:179-188

18. Sinha KK (1998) Detoxification of mycotoxins and food safety. In: Sinha KK, Bhatnagar D (eds) Mycotoxins in agriculture and food safety. Marcel Dekker, New York

19. Fuchs S, Sontag G, Stidl R, Ehrlich V, Kundi M, Knasmuller S (2008) Detoxification of patulin and ochratoxin A, two abundant mycotoxins, by lactic acid bacteria. Food Chem Toxicol 46:1398-1407

20. Abrunhosa L, Serra R, Venancio A (2002) Biodegradation of ochratoxin A by fungi isolated from grapes. J Agric Food Chem 50:493-7496

21. Angioni A, Caboni P, Garau A, Harris A, Orro D, Budroni M, Cabras P (2007) In vitro interaction between ochratoxin A and different strains of Saccharomyces cerevisiae and Kloeckera apiculata. J Agric Chem 55:2043-2048

22. Varga J, Rigo K, Teren J (2000) Degradation of ochratoxin A by Aspergillus species. Int J Food Microbiol 59:1-7

23. Shetty PH, Hald B, Jespersen L (2007) Surface binding of aflatoxin B1 by Saccharomyces cerevisiae strains with potential decontaminating abilities in indigenous fermented foods. Int $\mathbf{J}$ Food Microbiol 113:41-46

24. Haskard C, El-Nezami H, Kankaanpää P, Salminen S, Ahokas J (2001) Surface binding of aflatoxinB1 by lactic acid bacteria. Appl Environ Microbiol 67:3086-3091

25. Mateo EM, Medina A, Mateo F, Valle-Algarra FM, Pardo I (2010) Ochratoxin A removal in synthetic media by living and heat-inactivated cells of Oenococcus oeni isolated from wines. Food Control 21:23-28

26. Cecchini F, Morassut M, Moruno EG, Di Stefano R (2006) Influence of yeast strain on ochratoxin A content during fermentation of white and red must. Food Microbiol 23:411-417

27. Bejaoui H, Mathieu F, Taillandier P, Lebrihi A (2004) Ochratoxin A removal in synthetic and natural grape juices by selected oenological Saccharomyces cerevisiae strains. J Appl Microbiol 97:1038-1044

28. Piotrowska M, Żakowska Z (2000) The biodegradation of ochratoxin $\mathrm{A}$ in food products by lactic acid bacteria and baker's yeast. Food Biotechnol 17:307-310

29. Scott PM, Kanhere SR, Lawrence GA, Daley EF, Farber JM (1995) Fermentation of wort co containing ochratoxin A and fumonisins $\mathrm{B}_{1}$ and $\mathrm{B}_{2}$. Food Addit Contam1:31-40

30. Caridi A, Galvano F, Tafuri A, Ritieni A (2006) Ochratoxin A removal during winemaking. Enzym Microb Technol 40:122-126

31. Var I, Erginkaya Z, Kabak B (2009) Reduction of ochratoxin A levels in white wine by yeast treatments. J Inst Brew 115(1):30-33

32. Meca G, Blaiotta G, Ritieni A (2010) Reduction of ochratoxin A during the fermentation of Italian red wine Moscato. Food Control 21:579-583

33. Piotrowska M (2012) Adsorption of ochratoxin A by Saccharomyces cerevisiae living and non-living cells. Acta Aliment 41(1):1-7

34. Caridi A (2006) Enological functions of parietal yeast mannoproteins. Antonie Van Leeuwenhoek 89:417-422

35. Piotrowska M, Żakowska Z (2004) The elimination of ochratoxin A by Saccharomyces yeast's. Proceedings of VII International Conference "Mycotoxins and pathogenic mould in the environment", Bydgoszcz, 189-193

36. Wzorek W, Pogorzelski E (1998) Fruit and grape winemaking. Sigma NOT, Warsaw 
37. Zwietering MH, Jongenburger I, Rombouts FM, Van Triet $\mathrm{K}$ (1990) Modeling of the bacterial growth curve. Appl Environ Microbiol 56(6):1875-1881

38. Gutarowska B, Czyżowska A (2009) The ability of filamentous fungi to produce acids on indoor building materials. Ann Microbiol 59(4):807-881

39. Zlotnik H, Fernandez MP, Bowers B, Cabib E (1984) Saccharomyces cerevisiae mannoproteins form an external cell wall layer that determines wall porosity. J Bacteriol 159: 1018-1026
40. Pozo-Bayon MA, Andujar-Ortiz I, Moreno-Arribas MV (2009) Scientific evidences beyond the application of inactive dry yeast preparations in winemaking. Food Res Int 42:754-761

41. Castellari M, Versari A, Fabiani A, Parpinello GP, Galassi S (2001) Removal of ochratoxin A in red wines by means of adsorption treatments with commercial fining agents. J Agric Food Chem 49:3917-3921

42. Bizaj E, Mavri J, Cus F, Raspor A (2009) Removal of ochratoxin A in Saccharomyces cerevisiae liquid cultures. S Afr J Enol Vitic 30(2):151-155 